\title{
LAGOSTOMUS TELENKECHANUM, SP. NOV., A NEW LAGOSTOMINE RODENT (CAVIOMORPHA, CHINCHILLIDAE) FROM THE ARROYO CHASICÓ FORMATION (LATE MIOCENE; BUENOS AIRES PROVINCE, ARGENTINA)
}

\author{
LUCIANO L. RASIA (D) * and ADRIANA M. CANDELA \\ División Paleontología Vertebrados, Museo de La Plata, Paseo del Bosque s/n, B1900FWA La Plata, Argentina, and CONICET, \\ lucianorasia@conicet.gov.ar; acandela@museo.fcnym.unlp.edu.ar
}

\begin{abstract}
We describe a new lagostomine rodent (Caviomorpha, Chinchillidae), Lagostomus telenkechanum, sp. nov., from the Arroyo Chasicó Formation (late Miocene; Buenos Aires Province, Argentina). Three characters permit its assignment to Lagostomus: suborbital canal for the infraorbital nerve limited by a bony lamina, well-developed posterior process of the palatine, and posterior maxillary foramen located at the midpoint of the M3. In addition, we identify the new species based on a unique character combination (e.g., small size, palatines reaching anterior to the level of the midpoint of $\mathrm{P} 4$, anterior margin of mesopterygoid fossa at the level of the anterior border of M3, upper cheek teeth more compressed anteroposteriorly and more obliquely implanted in the maxilla than in L. pretrichodactyla, L. compressidens, and L. maximus but less than in L. incisus, and thick cement layer in the hypoflexus). Because the early Miocene-middle Miocene genera, Prolagostomus and Pliolagostomus, are no longer recorded from the late Miocene, whereas the oldest record of the extant genus Lagostomus is recognized at that time, we consider this period as an important turnover time in the taxonomic composition of the Chinchillidae. This study increases understanding of the taxonomic diversity of the late Cenozoic lagostomines, contributing to the knowledge of the evolutionary and paleobiogeographic history of chinchillids.
\end{abstract}

http://zoobank.org/urn:lsid:zoobank.org:pub:36EF6949-4226-492C-90A6-C51658852AD7

SUPPLEMENTAL DATA—Supplemental materials are available for this article for free at www.tandfonline.com/UJVP

Citation for this article: Rasia, L. L., and A. M. Candela. 2016. Lagostomus telenkechanum, sp. nov., a new lagostomine rodent (Caviomorpha, Chinchillidae) from the Arroyo Chasicó Formation (late Miocene; Buenos Aires Province, Argentina). Journal of Vertebrate Paleontology. DOI: 10.1080/02724634.2017.1239205.

\section{INTRODUCTION}

The subfamily Lagostominae-a group of caviomorph rodents included in the family Chinchillidae-is represented by a single living species, Lagostomus maximus (Desmarest, 1817), commonly known as the plains viscacha. Lagostomus maximus occurs in a wide variety of lowland habitats in Argentina, Bolivia, and Paraguay (Jackson et al., 1996), including the Pampas and adjoining semiarid Monte and Chaquenean regions (e.g., Spotorno and Patton, 2015). Some peculiar aspects of its biology include a marked sexual dimorphism, gregarious and nocturnal habits, and semifossoriality (Weir, 1974).

The Chinchillidae are known since the early Oligocene (e.g., Flynn et al., 2003; Bertrand et al., 2012), with an abundant fossil record in South America during the greater part of the Cenozoic (e.g., Ameghino, 1887, 1889; Scott, 1905; Vucetich, 1989; Rasia, 2016). Traditionally, fossils of Lagostominae from the late Miocene to late Pliocene have been assigned to Lagostomopsis (Kraglievich, 1926), identified either as a genus or as a subgenus of Lagostomus Brookes, 1828. Viscachas were diverse during the late Miocene-late Pliocene, with several nominal species recognized in Argentina (see Ameghino, 1883, 1886, 1888, 1891, 1908; Rovereto, 1914). The evolutionary history of Lagostominae during this

*Corresponding author. time period is poorly understood, and many of these species, with some exceptions (see Marshall and Patterson, 1981; Rasia and Candela, 2013, unpubl. data; Rasia, 2016), have not been revised since their original descriptions.

The Arroyo Chasicó Formation (Chasicoan Stage/Age, late Miocene; Tonni et al., 1998; Cione and Tonni, 2005) crops out in southwestern Buenos Aires Province, and its sediments contain abundant and diverse fossil mammals (e.g., Pascual, 1961; Pascual and Bondesio, 1968), which have been poorly studied in comparison with those of other units of the late Miocene of Argentina (e.g., Andalhuala, Cerro Azul, and Ituzaingó formations; Marshall and Patterson, 1981; Cione et al., 2000; Goin et al., 2000; Candela, 2005; Verzi et al., 2008; Brandoni, 2013; Bonini, 2014; Esteban et al., 2014).

The Lagostominae of the Arroyo Chasicó Formation are represented by numerous specimens, which constitute the oldest records for the Pampean region (Pascual, 1966; Bondesio et al., 1980; Vucetich, 1986), but they have not been evaluated in detail, being referred to Lagostominae indet. (Bondesio et al., 1980) and Lagostomopsis sp. (e.g., Pascual, 1966; Marshall et al., 1983; Vucetich, 1986; Cione and Tonni, 2001).

In this contribution, we describe numerous remains of Lagostominae from the late Miocene Arroyo Chasicó Formation, which represent a key record in the evolutionary history of the group, and evaluate biostratigraphically and paleobiogeographically related aspects, particularly in the context of the late Cenozoic of central Argentina. 


\section{MATERIALS AND METHODS}

\section{Abbreviations}

Institutional Abbreviations-MACN-A, Colección Nacional 'Florentino Ameghino,' Museo Argentino de Ciencias Naturales 'Bernardino Rivadavia,' Buenos Aires; MACN-Ma, Mastozoología, Museo Argentino de Ciencias Naturales 'Bernardino Rivadavia,' Buenos Aires; MACN-Pv, Colección Nacional Paleovertebrados, Museo Argentino de Ciencias Naturales 'Bernardino Rivadavia,' Buenos Aires; MASP, Museo Provincial de Ciencias Naturales de Paraná 'Antonio Serrano,' Paraná; MLP-Mz, Mastozoología, Museo de La Plata, La Plata; MLP-Pv, Paleontología Vertebrados, Museo de La Plata, La Plata. All institutions are located in Argentina.

Anatomical Abbreviations - almpf, anterior limit of mesopterygoid fossa; alPal, anterior limit of palatines; cp (br), coronoid process (broken); D, dentary; hc, horizontal crest; i1, lower incisor; ias, incisor alveolar sheet; M1, first upper molar; m1, first lower molar; M2, second upper molar; m2, second lower molar; M3, third upper molar; m3, third lower molar; mf, mandibular foramen; mn, masseteric notch (for the tendon of the M. masseter medialis pars anterior); mpf, mesopterygoid fossa; Mx, maxilla; P4, fourth upper premolar; p4, fourth lower premolar; Pal, palatine; pmf, posterior maxillary foramen, ppp, posterior process of palatine; rmf, retromolar fossa; soc, suborbital canal; zr (br), ventral zygomatic root (broken).

Other Abbreviations-ACF, Arroyo Chasicó Formation; APD, anteroposterior diameter; SALMA, South American Land Mammal Age; TD, transverse diameter.

\section{Quantitative Analysis}

Two linear measurements were taken from the upper (P4-M3) and lower ( $\mathrm{p} 4-\mathrm{m} 3)$ cheek teeth: the anteroposterior diameter (APD) and the transverse diameter (TD). The linear measurements were log-transformed and analyzed through principal component analysis (PCA) based on the correlation matrix (Bookstein et al., 1985; Legendre and Legendre, 1998). The free access program PAST 3.07 (Hammer et al., 2001) was used for the PCA. Missing data were replaced by iterative imputation (see Ilin and Raiko, 2010), also using PAST 3.07. Independent analyses were conducted for the upper and lower cheek teeth because maxillae and mandibles are not usually associated.

For PCA of the upper cheek teeth, specimens of the following species were included: Lagostomus telenkechanum, sp. nov.; $L$. pretrichodactyla (Rovereto, 1914); L. incisus Ameghino, 1888; L. euplasius (Ameghino, 1904); L. compressidens (Ameghino, 1904); L. cavifrons Ameghino, 1889; and L. maximus. For PCA of the lower cheek teeth, specimens of the following species were included: Lagostomus telenkechanum, sp. nov.; $L$. pretrichodactyla; L. antiquus Ameghino, 1883; L. incisus; L. euplasius; L. compressidens; L. debilis Ameghino, 1889; L. minimus Ameghino, 1889; L. heterogenidens Ameghino, 1889; L. egenus Ameghino, 1891; L. cavifrons; and L. maximus. The only extinct species of Lagostomus not included in the PCA were $L$. laminosus Ameghino, 1891, known by isolated lower cheek teeth, and 'L. pallidens' Ameghino, 1886, considered a nomen vanum (Rasia, 2016; All measurements used in PCA can be found in online Supplemental Data).

\section{LAGOSTOMINES FROM THE LATE MIOCENE AND THE VALIDITY OF LAGOSTOMOPSIS}

Lagostomopsis was erected as a subgenus of Lagostomus based on skull and postcranial characters (see Kraglievich, 1938). Within this subgenus, Kraglievich (1926) included all the species of Lagostomus described by Ameghino (1908) from the late Pliocene Chapadmalal 'Formation' and stated that this subgenus should probably include also the older species (i.e., those from the Monte Hermoso Formation, the 'Mesopotamiense' and the 'Araucanense'; late Miocene-early Pliocene; Ameghino, 1883, 1886, 1888, 1891; Rovereto, 1914). Later, Kraglievich (1938) considered Lagostomopsis as a genus distinct from Lagostomus. Conversely, Francis and Mones $(1965,1966,1968)$ stated that the differences between Lagostomus and Lagostomopsis were not sufficient to distinguish two genera, so they considered them to be subgenera. Thus, following these taxonomic proposals, all the Chasicoan (late Miocene) to Chapadmalalan (late Pliocene) records of Lagostominae have been assigned to Lagostomopsis (used either as a genus or subgenus of Lagostomus) whereas the post-Chapadmalalan records have been referred to Lagostomus (e.g., Pascual, 1966; Marshall et al., 1983; Vucetich and Verzi, 1995; Prado and Cerdeño, 1998; Cione and Toni, 2001; Tauber, 2005; Rasia and Candela, 2013).

The skull characters used to identify Lagostomopsis (e.g., small size, short nasals, long frontals, inflated temporal region, short paroccipital, and mastoid processes; see Kraglievich, 1926; Francis and Mones, 1965, 1966, 1968) are typical characters of juvenile and subadult individuals of the living species Lagostomus maximus (see Rasia et al., 2011; Rasia, 2016). Furthermore, a postcranial character mentioned by Kraglievich (1926) as a distinctive feature of Lagostomopsis - presence of a humeral supracondyloid canal-is only present in Lagostomus euplasius, being open or incomplete in L. incisus (Rasia and Candela, 2013, unpubl. data; Rasia, 2016). Moreover, this feature cannot be verified in other species traditionally grouped in Lagostomopsis due to the lack of preserved postcranial elements. Thus, neither the skull nor the postcranial characters allow for a clear differentiation between Lagostomus and Lagostomopsis.

In agreement with these morphological observations, a recent phylogenetic analysis (Rasia, 2016) does not support the validity of Lagostomopsis and includes all the late Miocene-Holocene species in the genus Lagostomus. Therefore, in this contribution, Lagostomus is considered the only valid genus, including all the species previously assigned to Lagostomopsis (used either as a genus or as subgenus).

\section{GEOLOGICAL SETTING}

The Arroyo Chasicó Formation (ACF) was formally described by Pascual (1961), based on the 'Chasicoense' of Kraglievich (1930). The type section of this unit (Pascual, 1961, 1965; Pascual et al., 1965) crops out on the lower Arroyo Chasicó, in southwestern Buenos Aires Province, Argentina (Fig. 1A). The ACF is composed of fine cross-bedded sandstones, which changes transitionally in the upper levels to sandy limestones with predominant sandy mudstones and limestones. There is a presence of intercalated paleosols in the entire succession (Fidalgo and Porro in Bondesio et al., 1980). Traditionally, two members are recognized within the ACF: the lower Vivero Member and the upper Las Barrancas Member, both distinguishable by their paleontological content and macroscopic features, such as mineralogy, texture, and structures (Fidalgo and Porro in Bondesio et al., 1980; Fidalgo et al., 1987). The 'Viveran' fauna was the basis of the 'Chasicotherium rothi biozone,' whereas the 'Barrancan' fauna was the basis of the 'Chasicotatus ameghinoi biozone,' delimiting the lower and upper Chasicoan Stage/Age, respectively (Tonni et al., 1998; Cione and Tonni, 2001, 2005; Fig. 1B). Nevertheless, a recent study (Zárate et al., 2007) indicates that there is no lithofacial evidence supporting a member differentiation within the ACF; therefore, the stratigraphic provenance of old fossil collections should be revised. Some studies on fossil vertebrates, especially rodents (e.g., Deschamps et al., 2007, 2009; Verzi et al., 2008), continue to accept the validity of the stratigraphic provenance of the fossils and correlate the Vivero Member with Lithofacies Associations 1 and 2, and the 


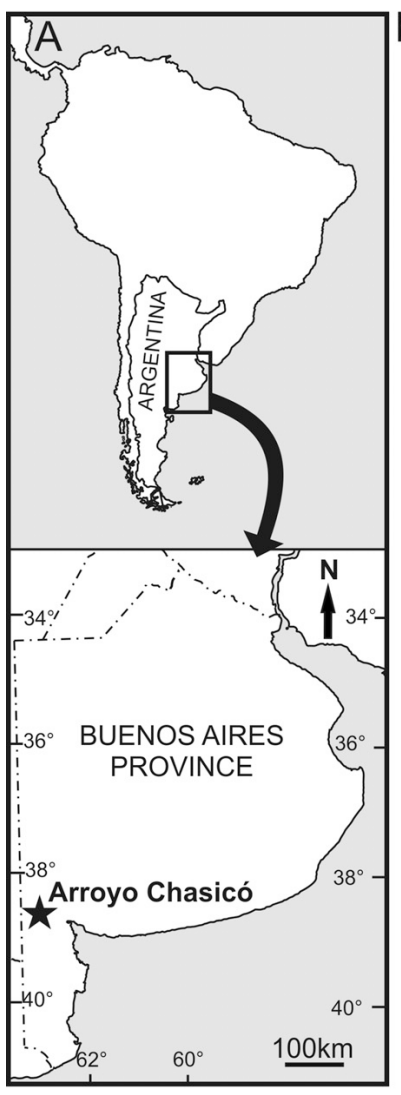

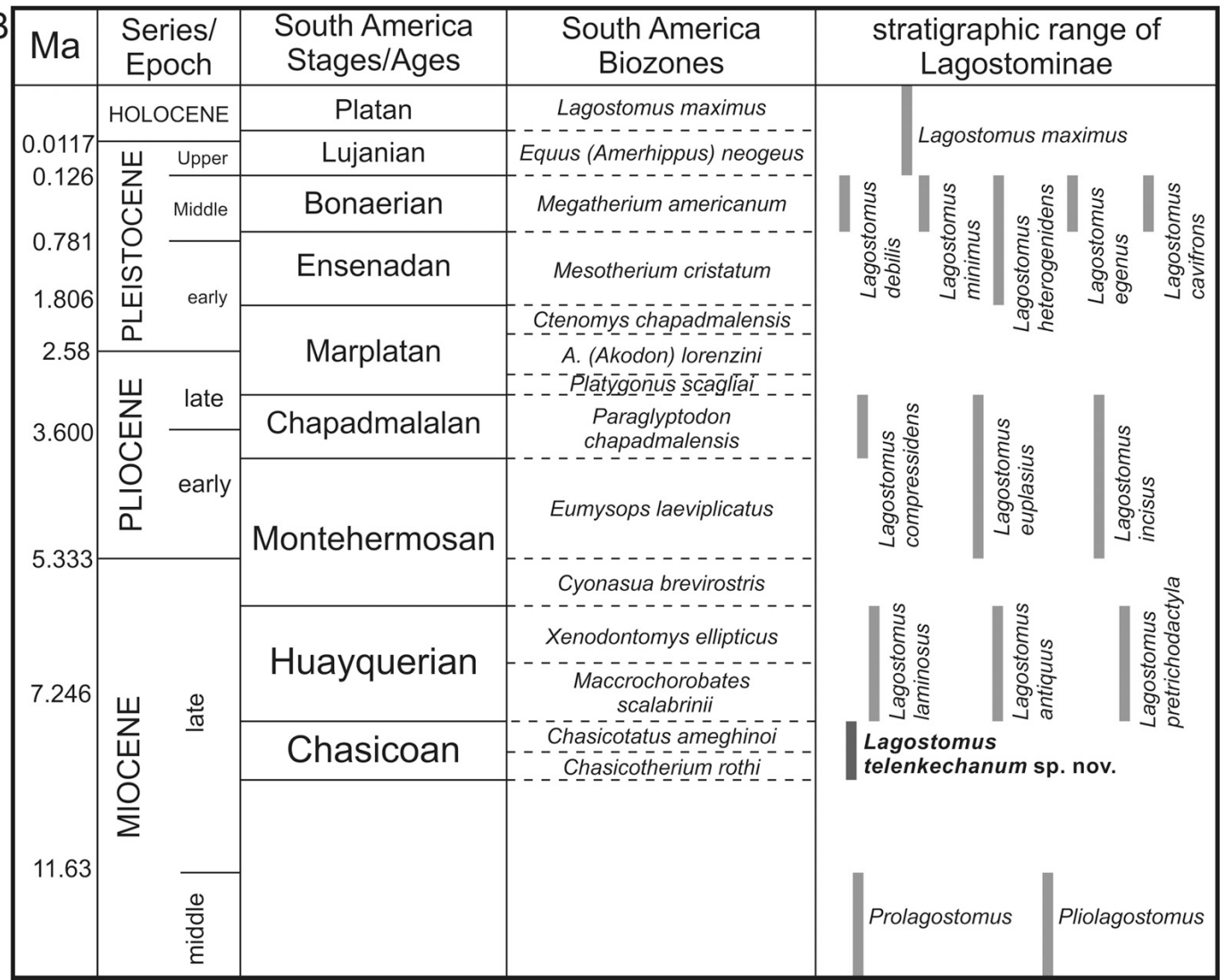

FIGURE 1. A, map showing Arroyo Chasicó locality; B, chronostratigraphic scheme showing stratigraphic distribution of Lagostominae. South American stages/ages following Cione and Tonni (2001, 2005), Reguero and Candela (2011), and Tomassini et al. (2013).

Las Barrancas Member with the Lithofacies Association 3, described by Zárate et al. (2007).

The age of the ACF was estimated to be between 11 and 3 Ma by Pascual et al. (1996). Later, Tonni et al. (1998) proposed a Tortonian age (late Miocene) for the ACF. Presently, the Chasicoan Stage/Age is placed between 10 and ca. $8.7 \mathrm{Ma}$ (Cione et al., 2000; Cione and Tonni, 2005). Datings on the basal levels of the ACF yielded an age of $9.23 \pm 0.09 \mathrm{Ma}$ (Schultz et al., 2004). A recent interpretation of radiometric and paleomagnetic data of the ACF supports an age between at least 9.43 and $8.7 \mathrm{Ma}$ (Zárate et al., 2007).

The material here studied comes from both the lower Vivero Member and the upper Las Barrancas Member (according to collector data), and some of the material does not have precise stratigraphic provenance within the ACF (those materials that were collected before a member differentiation within the $\mathrm{ACF}$ was established).

\section{SYSTEMATIC PALEONTOLOGY}

RODENTIA Bowdich, 1821

HYSTRICOGNATHI Tullberg, 1899

CAVIOMORPHA Wood and Patterson (in Wood, 1955)

CHINCHILLIDAE Bennett, 1833

LAGOSTOMINAE Wiegmann, 1835

Genus LAGOSTOMUS Brookes, 1828

Type Species-Lagostomus trichodactylus Brookes, 1828 (= Dipus maximus Desmarest, 1817).

\section{LAGOSTOMUS TELENKECHANUM, sp. nov.} (Figs. 2, 3A, 4)
Lagostomopsis sp. Pascual, 1966:122, lam. 49e, f.

Lagostominae indet. Bondesio, Laza, Scillato Yané, Tonni, and Vucetich, 1980:111.

Etymology-From the tehuelche 'telenke' (small), and 'chanum' (viscacha, actually referring to the mountain viscacha, Lagidium), for being one of the smallest species of Lagostomus.

Holotype-MLP-Pv 60-VI-18-100, palate with right and left P4-M3.

Hypodigm - The holotype and MLP-Pv 55-IV-28-42, left mandible fragment with broken i1, p4-m2, and broken m3; MLP-Pv 55-IV-28-43, portion of right maxilla with P4-M3; MLP-Pv 55IV-28-44, fragment of mandibular symphysis with left $\mathrm{p} 4-\mathrm{m} 1$; MLP-Pv 60-VI-18-101, right mandible fragment with $\mathrm{p} 4-\mathrm{m} 3$; MLP-Pv 60-VI-18-107, right mandible fragment with $\mathrm{p} 4$ and left mandible fragment with m1-m3; MLP-Pv 76-VI-12-47, left mandible fragment with $\mathrm{p} 4-\mathrm{m} 3$; MLP-Pv 92-XI-19-1, left mandible fragment with broken i1, p4, and broken m1-m2; MLP-Pv 92XI-19-2, left mandible fragment with p4-m3.

Locality and Horizon-Arroyo Chasicó area, southwest of Buenos Aires Province, Argentina (Fig. 1A). MLP-Pv 55-IV28-43 and MLP-Pv 55-IV-28-44 come from in front of Radovitzki farm; MLP-Pv 55-IV-28-42 comes from in front of Torres and Stefanazzi farms; MLP-Pv 60-VI-18-101 comes from the left margin of Stefanazzi farm; MLP-Pv 76-VI-12-47 comes from the left bank of Arroyo Chasicó, $400 \mathrm{~m}$ upstream from Bajada de los Toros; MLP-Pv 60-VI-18-100, MLP-Pv 60-VI-18-107, MLP-Pv 92-XI-19-1, and MLP-Pv 92-XI-19-2 come from the Arroyo Chasicó area, without more precise geographic provenance. 

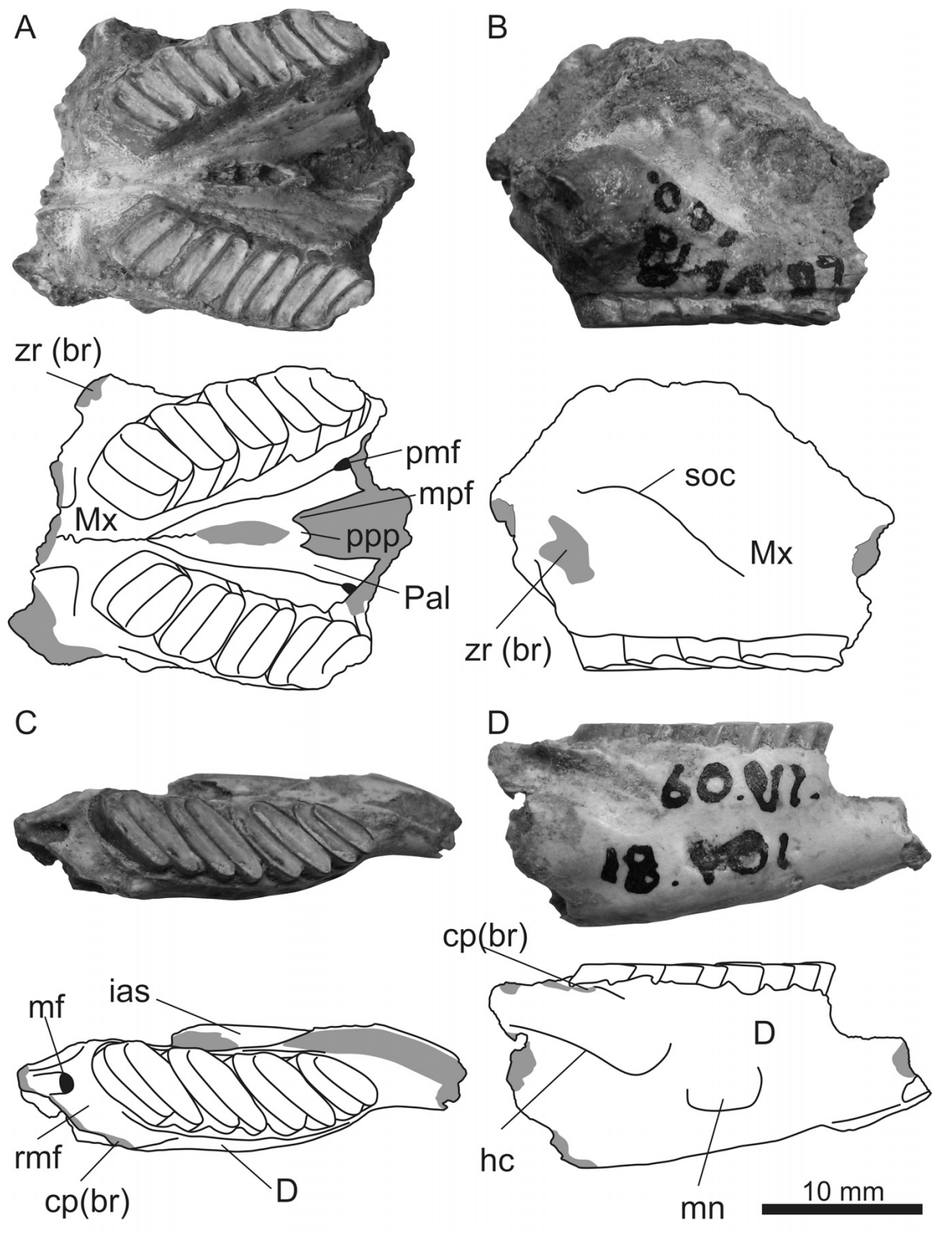

FIGURE 2. Lagostomus telenkechanum, sp. nov. Photographs and interpretative drawings. MLP-Pv 60-VI-18-100, holotype, palate in ventral (A) and lateral (B) views; MLP-Pv 60VI-18-101, right mandible in dorsal (C) and lateral (D) views. Abbreviations: cp (br), coronoid process (broken); D, dentary; hc, horizontal crest; ias, incisor alveolar sheet; mf, mandibular foramen; mn, masseteric notch; mpf, mesopterygoid fossa; Mx, maxilla; Pal, palatine; pmf, posterior maxillary foramen, ppp, posterior process of palatine; rmf, retromolar fossa; soc, suborbital canal; zr (br), ventral zygomatic root (broken).

All specimens come from the ACF (Chasicoan Stage/Age, late Miocene; Fig. 1B). Specimens MLP-Pv 55-IV-28-42, MLP-Pv 55-IV-28-43, MLP-Pv 55-IV-28-44, MLP-Pv 60-VI-18-100, MLPPv 60-VI-18-101, and MLP-Pv 60-VI-18-107 do not have precise provenance within the ACF because they were collected before the unit was subdivided into two members. Specimens MLP-Pv 92-XI-19-1 and MLP-Pv 92-XI-19-2 come from the Vivero Member of the ACF; and MLP-Pv 76-VI-12-47 comes from the Las Barrancas Member of the ACF.

Diagnosis-Lagostomine differing from all other species of Lagostomus by the following character combination: size smaller than all the other species, except for L. laminosus; portion of maxilla between cheek tooth alveoli and palatine suture flat; palatines extended anteriorly to the level of the midpoint of P4, forming most of the palate; anterior margin of the mesopterygoid fossa at the level of the anterior border of M3; upper cheek teeth more compressed anteroposteriorly and more obliquely implanted in the maxilla than in L. pretrichodactyla, L. compressidens, and L. maximus, but less than in L. incisus; and cement in the hypoflexus thicker than in $L$. incisus, L. compressidens, $L$. cavifrons, and L. maximus.

\section{Description and Comparisons}

Lagostomus telenkechanum, sp. nov., is one of the smallest species of the genus, with L. laminosus (from the 'Conglomerado Osífero' of the Ituzaingó Formation, late Miocene; Cione et al., 2000; Brandoni, 2013; see Fig. 1B) being the smallest species.

Skull-In the two known specimens with skull portions preserved (MLP-Pv 60-VI-18-100 and MLP-Pv 55-IV-28-43), there is a separate canal for the suborbital nerve in the medioventral surface of the infraorbital foramen, delimited by a well-developed bony lamina (Fig. 2B), as in the other species of the genus (Rasia, 2016) and some Echimyidae (e.g., Patton, 1987) and Caviidae (e.g., Quintana, 1996). There is no separate suborbital canal in Prolagostomus Ameghino, 1887 or Pliolagostomus Ameghino, 1887. Like in Lagostomus pretrichodactyla and L. euplasius, in L. telenkechanum, sp. nov., the maxilla is flat between the cheek 

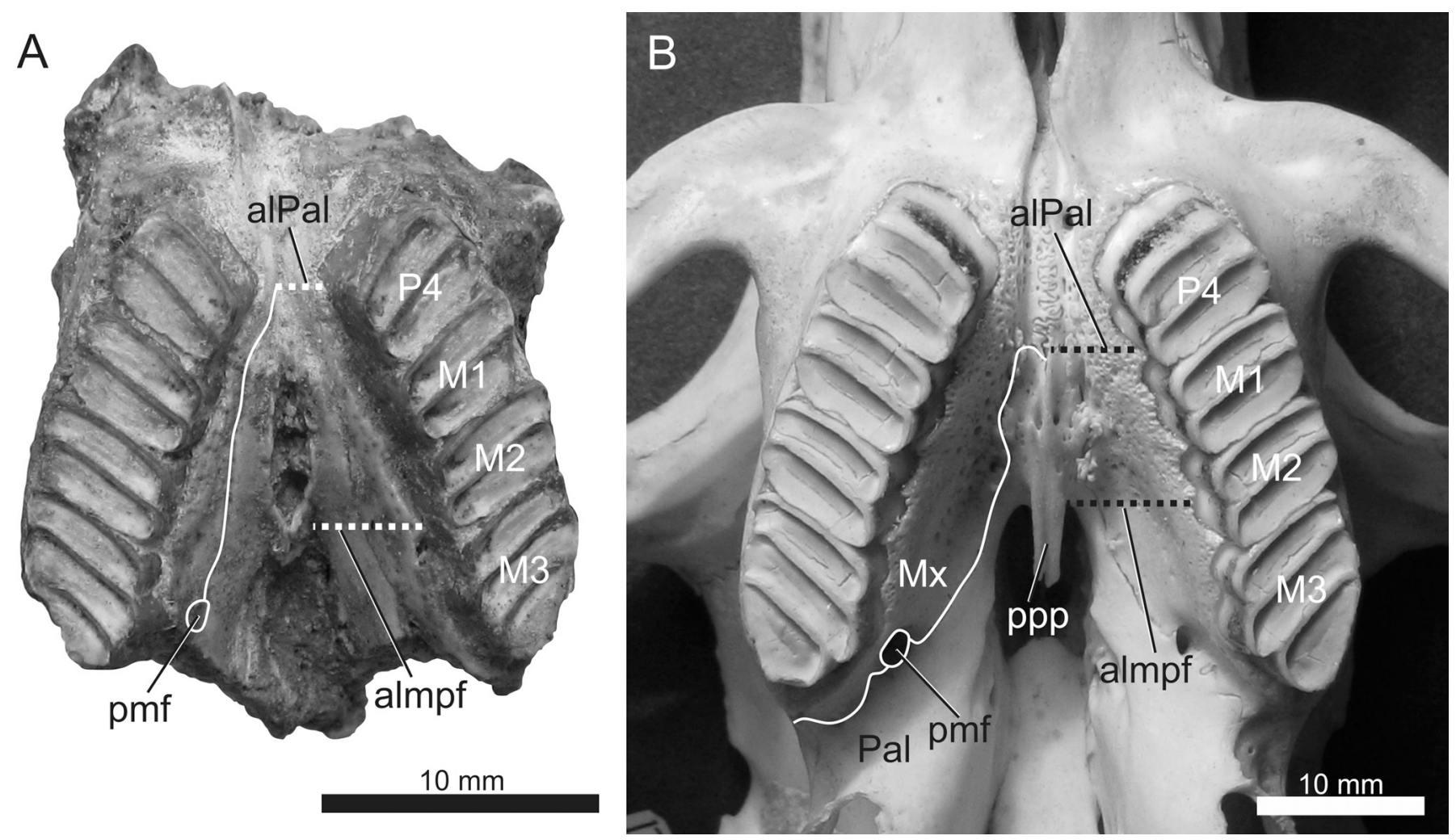

FIGURE 3. Comparison between Lagostomus telenkechanum, sp. nov. (A), and Lagostomus maximus (B). Maxilla-palatine suture indicated as a continuous white line. A, MLP-Pv 60-VI-18-100, holotype; B, MACN-Ma 49.13. Abbreviations: almpf, anterior limit of mesopterygoid fossa; alPal, anterior limit of palatines; M1-M3, upper molars; Mx, maxilla; P4, fourth upper premolar; pmf, posterior maxillary foramen; ppp, posterior process of palatines.

tooth alveoli and the palatine suture. In this feature, the new species differs from L. maximus, L. cavifrons, and L. compressidens, which have a shallow depression between the cheek tooth alveoli and the maxilla-palatine suture (Fig. 3). Palatines form a more important portion of the palate (Figs. 2A, 3A) than in L. maximus (Fig. 3) and extinct species of Lagostomus, but not than in Prolagostomus and Pliolagostomus, in which the palate is almost completely formed by the palatines. The palatines reach anteriorly to the midpoint of P4 (Figs. 2A, 3A), whereas in the other species of Lagostomus (i.e., L. pretrichodactyla, L. euplasius, $L$. compressidens, L. cavifrons, and L. maximus), the palatines reach the posterior end of the P4 (Fig. 3B). Despite that the palatines are broken in the medial portion, it is possible to observe that the posterior process of the palatines is present and well developed (Fig. 2A), as in other species of Lagostomus (Fig. 3B). The degree of development of the posterior process of the palatines varies in the living $L$. maximus, being either long (Fig. 3B) or short. In contrast, the posterior process of the palatines is poorly developed in Prolagostomus, Pliolagostomus, and the living chinchillines Chinchilla Bennett, 1829, and Lagidium Meyen, 1933. The posterior maxillary foramen is located at the midpoint of the M3 (Figs. 2A, 3A), like in all the other species of Lagostomus (Fig. 3B). In the extinct lagostomines Prolagostomus and Pliolagostomus, and in the living chinchillines Chinchilla and Lagidium, the posterior maxillary foramen is located posterior to the M3. The anterior margin of the mesopterygoid fossa is located at the level of the anterior border of the M3 (Figs. 2A, 3A), like in Prolagostomus and Pliolagostomus. In L. pretrichodactyla, L. euplasius, L. incisus, L. compressidens, $L$. cavifrons, and L. maximus, the mesopterygoid fossa reaches the midpoint of the M2 (Fig. 3B).
Mandibles-The lower diastema is shorter than the lower cheek tooth series, as in other lagostomines. The masseteric notch for the tendon of the M. masseter medialis pars anterior (sensu Woods, 1972; = pars infraorbitalis, sensu Woods and Howland, 1979) is located between the midpoint of $\mathrm{m} 1$ and the posterior end of $\mathrm{m} 2$ (Fig. 2D). The mandible body is higher and more robust than that of a juvenile specimen of Lagostomus maximus of equal size. The mandibular foramen is located on the lingual portion of the retromolar fossa (Fig. 2C), like in the other Lagostominae. The coronoid process is broken at its base in all specimens (Fig. 2C, D). The horizontal crest, delimiting the lateral masseteric fossa for the insertion of the M. masseter medialis pars posterior (sensu Woods, 1972; = pars zygomaticomandibularis posterior, sensu Woods and Howland, 1979), does not differ from that of other species of Lagostomus.

Upper Teeth-The upper incisors are not known. The upper cheek teeth have two rectangular lobes, except for the M3, which has three lobes, like all lagostomines. The upper cheek teeth are more compressed anteroposteriorly than in L. pretrichodactyla, L. compressidens, and L. maximus, but less than in L. incisus, and approximately equal to L. cavifrons and L. euplasius (see Table 1). In addition, the upper cheek teeth are more obliquely implanted in the maxillae with respect to the sagittal plane than in L. maximus, L. compressidens, and L. pretrichodactyla, but less than in $L$. incisus, and approximately equal to those of $L$. cavifrons and L. euplasius. The cement layer of the hypoflexus is slightly thinner than the enamel layer of the teeth. Cement is thicker than in L. incisus, L. compressidens, L. cavifrons, and $L$. maximus. The enamel layer is thick on the anterior face of both lobes and in the lingual face of all upper cheek teeth, and it is very thin or absent on the labial face of upper cheek teeth 
Rasia and Candela-New lagostomine rodent from Argentina (e1239205-6)

TABLE1. Measurements (in mm) of cheek teeth of Lagostomus telenkechanum, sp. nov.

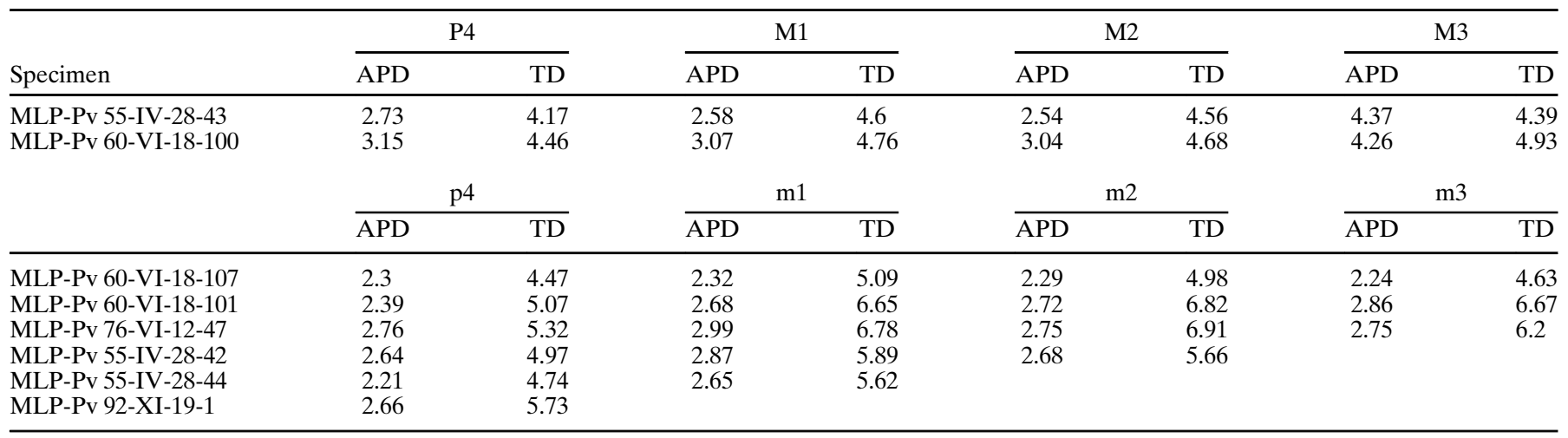

(Fig. 4A). The P4 has almost straight borders. The anterior lobe is rectangular, and the posterior lobe is lingually thinner and subtriangular. In M1 and M2, the anterior lobe is more labially projected than the posterior one, like in most species of Lagostomus, but not as projected as in Prolagostomus. A very narrow dentine bridge joins the second and third lobes of the M3 labially (Fig. 4A), as in young individuals of L. maximus. In Prolagostomus and Pliolagostomus, the second and third lobes of the M3 are labially continuous by a thick bridge of dentine. The third lobe of the M3 is triangular and is not as developed as in L. maximus, L. cavifrons, L. compressidens, and L. incisus.

Lower Teeth-The lower incisor is deeply implanted in the mandible, reaching the posterior end of $\mathrm{m} 3$, like in the other species of the genus, except for Lagostomus compressidens (Rasia and Candela, unpubl. data). The enamel of the anterior face of the incisor is yellowish, like in L. euplasius (Rasia, 2016; Rasia and Candela, unpubl. data). The lower cheek teeth have two lobes like all lagostomines. Also, they are more compressed anteroposteriorly than in L. maximus, L. cavifrons, L. egenus, L. debilis, L. minimus, L. heterogenidens, L. compressidens, and L. pretrichodactyla, but less compressed than in L. laminosus and L. incisus, and similar to those of L. antiquus and L. euplasius (see Table 1). The lower cheek teeth are more obliquely implanted in the mandible than in L. pretrichodactyla, L. compressidens, L. cavifrons, and L. maximus, but less than in L. incisus, and approximately equal to L. antiquus, L. euplasius, L. debilis, $L$. heterogenidens, and L. minimus. There is no enamel on the anterior face of the posterior lobe in the lower cheek teeth. The enamel is thick in the posterior face of the first and second lobes, and in the lingual portion of the anterior face of lower cheek teeth. In addition, the enamel is thin in the lingual face of all check teeth (Fig. 4B). There is a layer of cement in the hypoflexid of all lower cheek teeth (Fig. 4B), which is thicker than in L. incisus, L. compressidens, L. debilis, L. minimus, L. heterogenidens, L. cavifrons, and $L$. maximus, but similar to $L$. pretrichodactyla, L. antiquus, and L. euplasius.

\section{QUANTITATIVE ANALYSES}

\section{Upper Cheek Teeth}

For the PCA using upper cheek teeth, the first principal component (PC1) essentially represents size, given that all variables have high positive loadings (see Table 2). The smaller specimens have lower scores on PC1, and the larger ones have higher scores. The smallest species analyzed is Lagostomus telenkechanum, sp. nov., with a size equivalent to that of some juvenile specimens of $L$. maximus. The biggest species are L. maximus, L. cavifrons, L. compressidens, and L. incisus (see Fig. 5A).

The second principal component (PC2) represents variation in APD of P4, APD and TD of M1 and M2, and TD of M3 (see Table 2). The species with the greatest anteroposterior compression of the upper cheek teeth is Lagostomus incisus, with negative scores. Lagostomus telenkechanum, sp. nov., $L$. euplasius, and L. cavifrons have moderately anteroposteriorly compressed upper cheek teeth. The rest of the species (L. pretrichodactyla, L. compressidens, and L. maximus) have less compressed cheek teeth, with positive scores (see Fig. 5A).
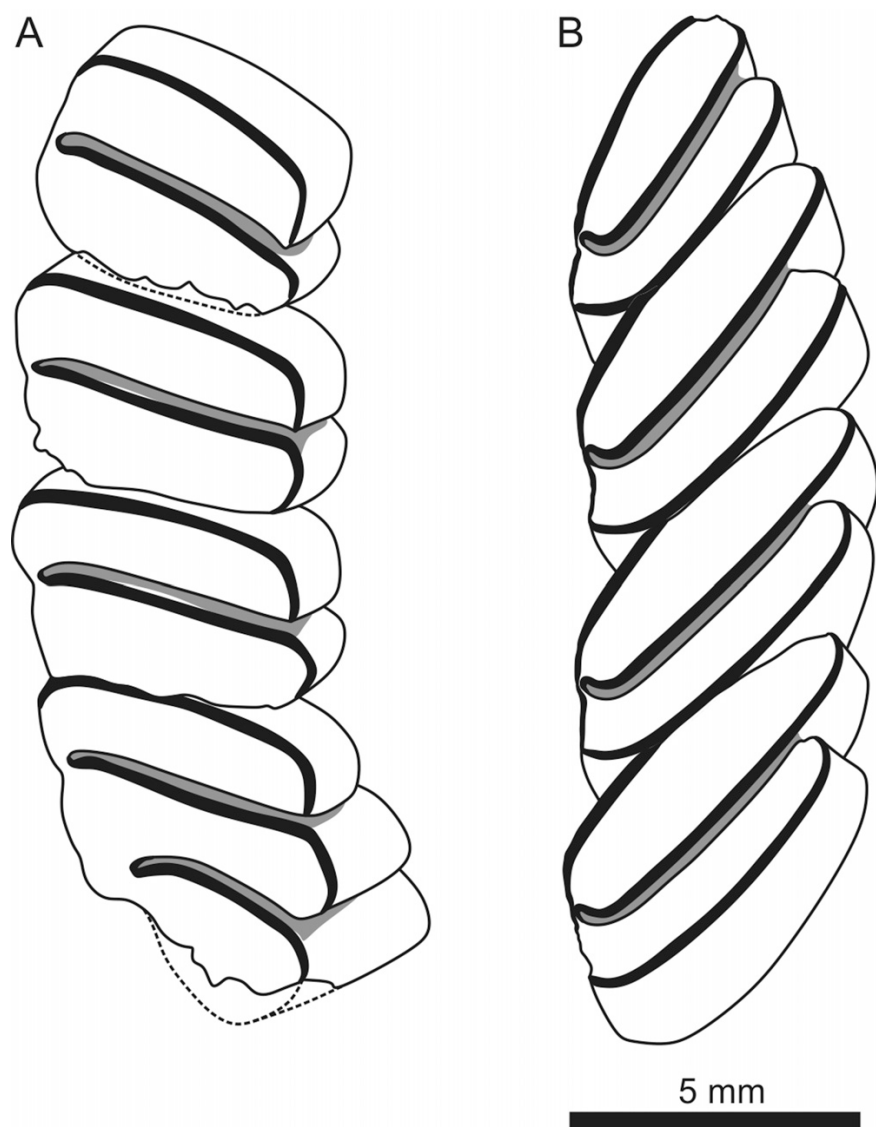

FIGURE 4. Lagostomus telenkechanum, sp. nov. Schematic drawings of cheek teeth. A, MLP-Pv 60-VI-18-100, holotype, upper right cheek teeth; B, MLP-Pv 60-VI-18-101, lower right cheek teeth. Black: enamel; gray: cement; and white: dentine. 
TABLE 2. Factor loadings for PC1 and PC2 of PCA of upper and lower cheek teeth.

\begin{tabular}{llrlllr}
\hline \multicolumn{3}{c}{ Upper cheek teeth } & & \multicolumn{3}{c}{ Lower cheek teeth } \\
\cline { 1 - 2 } Dimension & PC1 & PC2 & & Dimension & PC1 & PC2 \\
\hline P4 APD & 0.296 & 0.422 & & p4 APD & 0.371 & 0.334 \\
P4 TD & 0.382 & -0.149 & & p4 TD & 0.376 & -0.102 \\
M1 APD & 0.312 & 0.366 & & m1 APD & 0.308 & 0.385 \\
M1 TD & 0.371 & -0.240 & & m1 TD & 0.350 & -0.249 \\
M2 APD & 0.325 & 0.389 & & m2 APD & 0.311 & 0.399 \\
M2 TD & 0.368 & -0.319 & & m2 TD & 0.363 & -0.401 \\
M3 APD & 0.366 & 0.284 & & m3 APD & 0.313 & 0.341 \\
M3 TD & 0.395 & -0.523 & & m3 TD & 0.420 & -0.481 \\
Eigenvalue & 0.319 & 0.023 & & Eigenvalue & 0.353 & 0.052 \\
\% variance & 90.273 & 6.625 & & \% variance & 84.773 & 12.471 \\
\hline
\end{tabular}

\section{Lower Cheek Teeth}

In the PCA of the lower cheek teeth, PC1 represents size, given that all variables have high positive loadings (see Table 2). The smaller specimens have lower scores, and the larger species have higher scores. As in the PCA of upper cheek teeth, Lagostomus telenkechanum, sp. nov., is the smallest species (see Fig. 5B). The larger species are L. maximus, L. cavifrons, L. egenus, L. debilis, L. compressidens, and L. incisus.

The PC2 represents variation in the APD and TD of the $\mathrm{m} 1-\mathrm{m} 3$ (see Table 2). Lagostomus incisus has the most compressed lower cheek teeth, with negative values of PC2. Species with a moderate compression of the lower cheek teeth are L. telenkechanum, sp. nov., L. antiquus, and L. euplasius, with values of $\mathrm{PC} 2$ close to 0 . Species with less compressed lower cheek teeth are L. pretrichodactyla, L. debilis, L. heterogenidens, L. minimus, L. cavifrons, L. egenus, and L. maximus, with positive scores of PC2 (see Fig. 5B).

According to these results, Lagostomus telenkechanum, sp. nov., can be distinguished from other species of Lagostomus by the general size and anteroposterior compression of the cheek teeth (more compressed than L. pretrichodactyla, L. compressidens, and L. maximus, but less than in L. incisus), supporting the diagnostic value of these characters (see Systematic Paleontology).

\section{DISCUSSION AND CONCLUSIONS}

\section{Generic Identity and Specific Status of Chasicoan Vizcachas}

The study of the Lagostominae from the ACF indicates that these are clearly distinguishable from the early and middle Miocene genera Prolagostomus and Pliolagostomus and that they belong to Lagostomus due to the presence of (1) suborbital canal limited by a bony lamina; (2) well-developed posterior process of the palatine; and (3) posterior maxillary foramen located at the midpoint of the M3 (see Rasia, 2016).

The comparative study shows that Lagostomus telenkechanum, sp. nov., constitutes a new species due to the following character combination: (1) small size; (2) portion of maxilla between cheek tooth alveoli and palatine suture flat; (3) palatines reaching anteriorly to the mid-point of the P4; (4) palatines forming most of the palate; (5) anterior margin of the mesopterygoid fossa at the level of the anterior border of M3; (6) upper cheek teeth more anteroposteriorly compressed; (7) upper cheek teeth more obliquely implanted than in L. pretrichodactyla, $L$. compressidens, and L. maximus, but less than in L. incisus; and (8) cement in the hypoflexus thicker than in L. incisus, L. compressidens, L. cavifrons, and L. maximus.
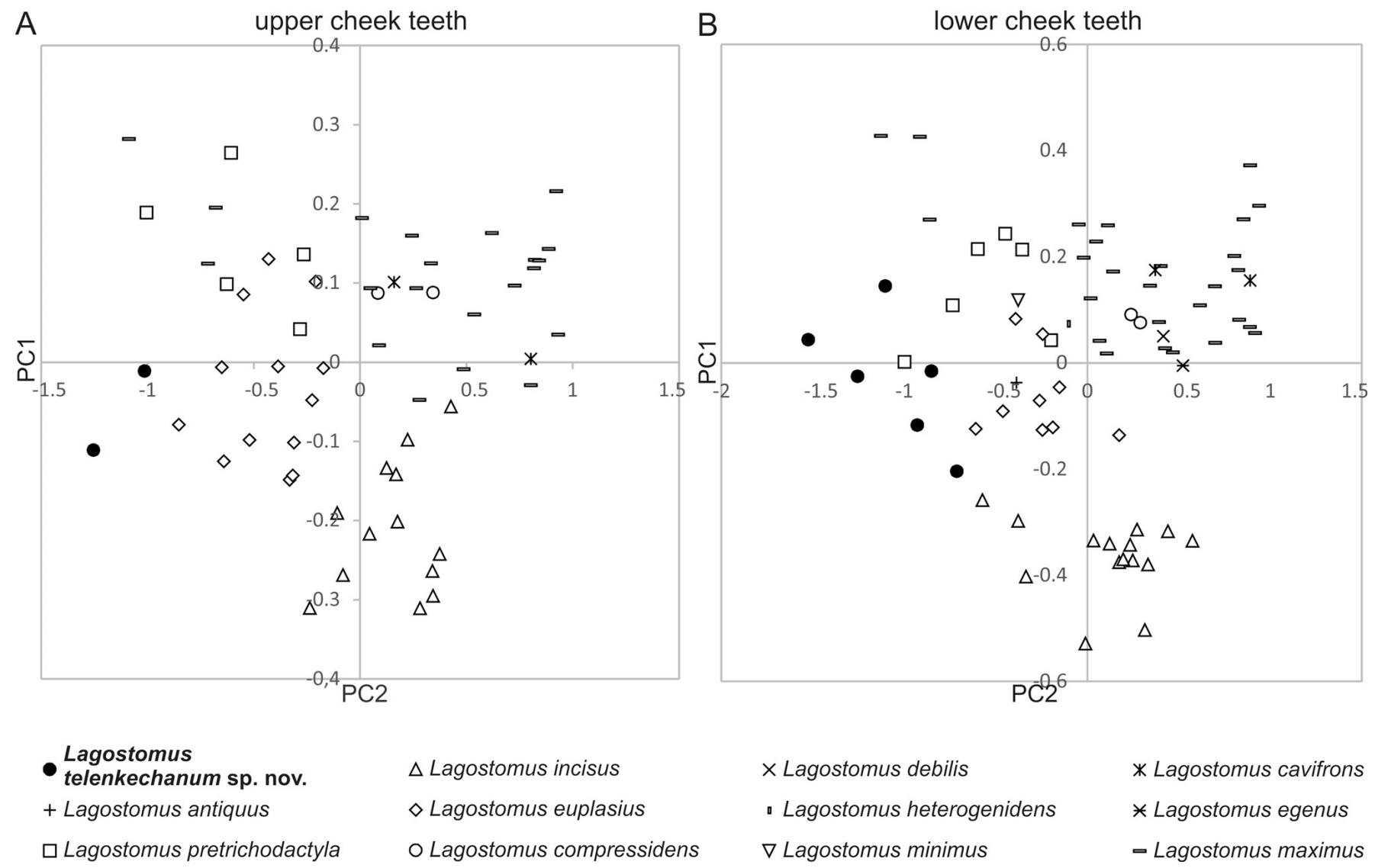

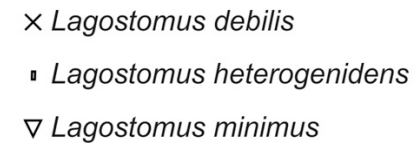

* Lagostomus cavifrons

* Lagostomus egenus

- Lagostomus maximus

FIGURE 5. Plot of scores of PC1 and PC2 for PCA of upper (A) and lower (B) cheek teeth. 
In addition, the referred material differs from other species of Lagostomus by the following character combination: (1) lower incisor with yellowish enamel; (2) lower cheek teeth more compressed anteroposteriorly than in $L$. maximus, $L$. cavifrons, L. egenus, L. debilis, L. minimus, L. heterogenidens, L. compressidens, and L. pretrichodactyla, and less than in L. laminosus and L. incisus; and (3) lower cheek teeth more obliquely implanted than in $L$. pretrichodactyla, $L$. compressidens, L. cavifrons, and L. maximus, but less than in L. incisus.

Thus, the qualitative and quantitative analyses support the validity of Lagostomus telenkechanum, sp. nov., as a new species of Lagostomus from the ACF. The identification of this species increases understanding of the taxonomic richness of Lagostomus since their earliest evolutionary history.

\section{Biostratigraphic and Paleobiogeographic Remarks}

Our study indicates that there are no confirmed records of Prolagostomus or Pliolagostomus in the ACF, in contrast to statements by several authors (Bondesio et al., 1980; Chick et al., 2008; Croft et al., 2011). The youngest records of Prolagostomus come from middle Miocene levels of Argentina (Vucetich, 1984; Vucetich et al., 1993), Bolivia (e.g., Marshall and Sempere, 1991; Croft et al., 2011), and Chile (Flynn et al., 2008). The youngest record of Pliolagostomus also comes from middle Miocene levels in Argentina (Vucetich, 1984).

In this regard, the Chasicoan Stage/Age (late Miocene) marks an important turnover of the taxonomic composition of the subfamily Lagostominae. Prolagostomus and Pliolagostomus - the typical genera of the early and middle Miocene-are no longer recorded during this stage/age, instead Lagostomus telenkechanum, sp. nov., is recognized as the oldest representative of the living genus Lagostomus and the oldest recorded lagostomine of the Pampean region. Currently, there are no definite records of lagostomines from the Laventan (middle Miocene) and Mayoan (early late Miocene) South American land mammal ages (SALMAs), but new findings would shed light on the precise onset of this taxonomic turnover.

The taxonomic study of fossil Lagostominae indicates that Lagostomus telenkechanum, sp. nov., is not identified in the younger units assigned to the Huayquerian Stage/Age (e.g., Andalhuala, Cerro Azul, and Ituzaingó formations; see Rasia, 2016). Until now, Huayquerian species are represented by $L$. pretrichodactyla, L. antiquus, and L. laminosus (Ameghino, 1883, 1891; Rovereto, 1914; Rasia, 2016; see Fig. 1B). Therefore, Lagostomus telenkechanum, sp. nov., seems to be restricted to the Chasicoan Stage/Age, and the end of the Miocene period could indicate a new and younger taxonomic turnover of Lagostominae, associated with an increasing specific richness of the genus.

The Chasicoan Stage/Age marks the beginning of the traditional 'Edad de las Planicies Australes,' the Age of the Southern Plains (Pascual and Bondesio, 1982), which was coeval with a global climatic deterioration and more marked seasonality than in the middle Miocene (e.g., Janis, 1993; Pascual et al., 1996), that occurred after the withdrawal of the Miocene 'mar Paranaense' (Paranean Sea; Pascual et al., 1996; Aceñolaza, 2000; Candela et al., 2012). Whether some of these environmental and biogeographic events were related to taxonomic changes in the lagostomines has not yet been examined, and could be better understood in the context of other groups of rodents. Caviomorphs recovered from the ACF, with some exceptions (Pascual, 1961, 1967; Pascual and Bondesio, 1968; Bondesio et al., 1980; Deschamps et al., 2007; Verzi et al., 2008; Pérez et al., 2014) have not been intensively studied. Therefore, analysis of the possible faunistic turnover between the Chasicoan and the Huayquerian occurring in other lineages of caviomorphs is pending.
The correct identification of the late Cenozoic species of lagostomines and their accurate stratigraphic provenance indicates that they are restricted to different times of the late MiocenePleistocene (see Fig. 2B). This suggests that the fossil species of Lagostomus could be good biostratigraphic tools for central Argentina during this period, where these rodents are particularly abundant.

Other records of Lagostominae, of uncertain specific status, have been reported from assemblages assigned to the Chasicoan Stage/Age, such as Assemblage A of the Loma de las Tapias Formation (San Juan Province; see Contreras and Baraldo, 2011) and the El Jarillal Member of the Chiquimil Formation (Catamarca Province; see Herbst et al., 2000; Esteban et al., 2014). Further studies of these materials could clarify their taxonomic status, confirming whether the distribution of Lagostomus telenkechanum, sp. nov., was restricted to the Pampean region or extended to the west and northwest of Argentina, or even to other areas of South America with late Miocene lagostomine records (Marshall and Sempere, 1991).

\section{ACKNOWLEDGMENTS}

We thank M. Reguero (MLP), D. Flores (MACN), A. Kramarz (MACN), I. Olivares (MLP), and D. Verzi (MLP) for access to collections. S. Gouiric-Cavalli made useful comments on an early version of the manuscript. A. Álvarez and M. D. Ercoli made valuable suggestions on the principal component analyses. We want to thank the associate editors M. Sánchez-Villagra and B. Anemone and two anonymous reviewers for the comments and suggestions that greatly improved the manuscript.

\section{ORCID}

Luciano L. Rasia (D) http://orcid.org/0000-0002-0300-4918

\section{LITERATURE CITED}

Aceñolaza, F. G. 2000. La Formación Paraná (Mioceno medio) estratigrafía, distribución regional y unidades equivalentes; pp. 9-28 in F. G. Aceñolaza and R. Herbst (eds.), El Neógeno de Argentina. Serie Correlación Geológica 14.

Ameghino, F. 1883. Sobre una nueva colección de mamíferos fósiles recogidos por el Profesor Scalabrini en las barrancas del Paraná. Boletín de la Academia Nacional de Ciencias de Córdoba 5:112113.

Ameghino, F. 1886. Contribución al conocimiento de los mamíferos fósiles de los terrenos terciarios antiguos de Paraná. Boletín de la Academia Nacional de Ciencias de Córdoba 9:5-228.

Ameghino, F. 1887. Enumeración sistemática de las especies de mamíferos fósiles coleccionados por Carlos Ameghino en los terrenos eocenos de Patagonia austral y depositados en el Museo de La Plata. Boletín del Museo de La Plata 1:1-26.

Ameghino, F. 1888. Lista de las especies de mamíferos fósiles del Mioceno superior de Monte Hermoso, hasta ahora conocidas. E. Coni, Buenos Aires, Argentina, $21 \mathrm{pp}$.

Ameghino, F. 1889. Contribución al conocimiento de los mamíferos fósiles de la República Argentina. Actas de la Academia Nacional de Ciencias de Córdoba 6:1-1027.

Ameghino, F. 1891. Mamíferos y aves fósiles argentinos. Especies nuevas, adiciónes y correcciónes. Revista Argentina de Historia Natural 1:240-259.

Ameghino, F. 1908. Las formaciones sedimentarias de la región litoral de Mar del Plata y Chapadmalal. Anales del Museo Nacional de Buenos Aires 10:342-428.

Bertrand, O. C., J. J. Flynn, D. A. Croft, and A. R. Wyss. 2012. Two new taxa (Caviomorpha, Rodentia) from the Early Oligocene Tinguiririca Fauna (Chile). American Museum Novitates 3750:1-36.

Bennett, E. T. 1829. The chinchilla. Gardens and Menagerie of the Zoological Society of London 1:1-12. 
Bennett, E. T. 1833. Remarks on the family Chinchillidae and on a new genus referrible [sic.] to it. Proceedings of the Zoological Society of London 1:57-60.

Bondesio, P., J. Laza, G. Scillato Yané, E. P. Tonni, and M. G. Vucetich 1980. Estado actual del conocimiento de los vertebrados de la Formación Arroyo Chasicó (Plioceno temprano) de la provincia de Buenos Aires; pp. 101-127 in II Congreso Argentino de Paleontología y Bioestratigrafía y I Congreso Latinoamericano de Paleontología, Buenos Aires, Actas, Volume 3.

Bonini, R. A. 2014. Bioestratigrafìa y diversidad de los mamíferos del Neógeno de San Fernando y Puerta de Corral Quemado (Catamarca, Argentina). Ph.D. dissertation, Facultad de Ciencias Naturales y Museo, Universidad Nacional de La Plata, La Plata, Argentina, $366 \mathrm{pp}$.

Bookstein, F. L., B. Chernoff, R. L. Elder, J. M. Humphries, G. R. Smith, and R. E. Strauss. 1985. Morphometrics in evolutionary biology. Special Publication, Academy of Natural Sciences Philadelphia 15:1-277.

Bowdich, T. E. 1821. An Analysis of the Natural Classifications of Mammalia for the Use of Students and Travelers. Smith, Paris, $115 \mathrm{pp}$

Brandoni, D. 2013. Los mamíferos continentales del "Mesopotamiense" (Mioceno tardío) de Entre Ríos, Argentina. Diversidad, edad y paleobiogeografía; pp. 179-191 in D. Brandoni and J. I. Noriega (eds.), El Neógeno de la Mesopotamia Argentina. Asociación Paleontológica Argentina, Publicación Especial 14.

Brookes, J. 1828. A new genus of the order Rodentia. Transactions of the Linnean Society 16:96-105.

Candela, A. M. 2005. Los roedores del "Mesopotamiense" (Mioceno tardío, Formación Ituzaingó) de la provincia de Entre Ríos (Argentina); pp. 37-48 in F. G. Aceñolaza (ed.), Temas de la Biodiversidad del Litoral Fluvial Argentino 2. INSUGEO Miscelánea 14.

Candela, A. M., R. A. Bonini, and J. I. Noriega. 2012. First continental vertebrates from the marine Paraná Formation (Late Miocene, Mesopotamia, Argentina): chronology, biogeography, and paleoenvironments. Geobios 45:515-526.

Chick, J., D. A. Croft, and F. Anaya. 2008. Middle Miocene rodents from Quebrada Honda, Bolivia. Journal of Vertebrate Paleontology 28 (3, Supplement):63A.

Cione, A. L., and E. P. Tonni. 2001. Correlation of Pliocene to Holocene southern South American and European vertebrate-bearing units. Bolletino della Societá Paleontologica Italiana 40:167-173.

Cione, A. L., and E. P. Tonni. 2005. Bioestratigrafía basada en mamíferos del Cenozoico superior de la provincia de Buenos Aires, Argentina; pp. 183-200 in R. E. de Barrio, R. O. Etcheverry, M. F. Caballé, and E. Llambías (eds.), Geología y Recursos Minerales de la Provincia de Buenos Aires. Relatorio del XVI Congreso Geológico Argentino, La Plata.

Cione, A. L., M. Azpelicueta, M. Bond, A. A. Carlini, J. R. Casciotta, M. A. Cozzuol, M. S. de la Fuente, Z. Gasparini, F. Goin, J. I. Noriega, G. J. Scillato-Yané, L. Soilbelzon, E. P. Tonni, D. Verzi, and M. G. Vucetich. 2000. Miocene vertebrates from Entre Ríos Province, eastern Argentina; pp. 191-237 in F. G. Aceñolaza and R. Herbst (eds.), El Neógeno de Argentina. Serie Correlación Geológica 14.

Contreras, V. H., and J. A. Baraldo. 2011. Calibration of the ChasicoanHuayquerian stages boundary (Neogene), San Juan, western Argentina; pp. 111-121 in J. A. Salfity and R. A. Marquillas (eds.), Cenozoic Geology of the Central Andes of Argentina. SCS, Salta.

Croft, D. A., J. M. H. Chick, and F. Anaya. 2011. New Middle Miocene Caviomorph Rodents from Quebrada Honda, Bolivia. Journal of Mammalian Evolution 18:245-268.

Deschamps, C. M., A. I. Olivares, E. C. Vieytes, and M. G. Vucetich. 2007. Ontogeny and diversity of the oldest capybaras (Rodentia: Hydrochoeridae; late Miocene of Argentina). Journal of Vertebrate Paleontology 27:683-692.

Deschamps, C. M., E. C. Vieytes, A. I. Olivares, and M. G. Vucetich. 2009. Primer registro de Cardiatherium chasicoense (Rodentia, Hydrochoeridae) fuera del área pampeana (Argentina) y su valor bioestratigráfico. Ameghiniana 46:295-305.

Desmarest, A. G. 1817. Gerboise première espèce: la grande gerboise Dipus maximus Blainv. Nouveau Dictionnaire d'Histoire Naturelle 13:117-119.

Esteban, G., N. Nasif, and S. M. Georgieff. 2014. Cronobioestratigrafía del Mioceno tardío - Plioceno temprano, Puerta de Corral Quemado y Villavil, provincia de Catamarca, Argentina. Acta Geológica Lilloana 26:165-192.
Fidalgo, F., E. P. Tonni, N. Porro, and J. H. Laza. 1987. Geología del área de la Laguna Chasicó (Partido de Villarino, Provincia de Buenos Aires) y aspectos bioestratigráficos relacionados. Revista de la Asociación Geológica Argentina 42:407-416.

Flynn, J. J., A. R. Wyss, D. A. Croft, and R. Charrier. 2003. The Tinguiririca Fauna, Chile: biochronology, paleoecology, biogeography, and a new earliest Oligocene South American Land Mammal 'Age'. Palaeogeography, Palaeoclimatology, Palaeoecology 195:229-259.

Flynn, J. J., R. Charrier, D. A. Croft, P. B. Gans, T. M. Herriott, J. A. Wertheim, and A. R. Wyss. 2008. Chronologic implications of new Miocene mammals from the Cura-Mallín and Trapa Trapa formations, Laguna del Laja area, south central Chile. Journal of South American Earth Sciences 26:412-423.

Francis, J. C., and A. Mones. 1965. La presencia de vizcachas [Lagostomus (Lagostomopsis) spicatus (Amegh.)] en la Formación Kiyú, Dto. de San José, R. O. del Uruguay. Revista de la Facultad de Humanidades y Ciencias, Montevideo 22:155-168.

Francis, J. C., and A. Mones. 1966. Las vizcachas, Lagostomus (Lagostomopsis) euplasius (Amegh.), de la formación Maldonado, departamento de Maldonado, República Oriental del Uruguay. Kraglieviana 1:101-110.

Francis, J. C., and A. Mones. 1968. Los roedores fósiles del Uruguay. Boletín del Laboratorio de Paleontología de Vertebrados 1:35-55.

Goin, F. J., C. I. Montalvo, and G. Visconti. 2000. Los Marsupiales (Mammalia) del Mioceno Superior de la Formación Cerro Azul (Provincia de La Pampa, Argentina. Estudios Geológicos 56:101126.

Hammer, O., D. A. T. Harper, and P. D. Ryan. 2001. PAST: Paleontological Statistics software package for education and data analysis. Palaeontologia Electronica 4:1-9.

Herbst, R., L. M. Anzótegui, G. Esteban, L. R. Mautino, L. S. Morton, and N. Nasif. 2000. Síntesis paleontológica del Mioceno de los Valles Calchaquíes, noroeste argentino; pp. 263-288 in F. G. Aceñolaza and R. Herbst (eds.), El Neógeno de Argentina. Serie Correlación Geológica 14.

Ilin, A., and T. Raiko. 2010. Practical approaches to Principal Component Analysis in the presence of missing values. Journal of Machine Learning Research 11:1957-2000.

Jackson, J. E., L. C., Branch, and D. Villareal. 1996. Lagostomus maximus. Mammalian Species 543:1-6.

Janis, C. M. 1993. Tertiary mammal evolution in the context of changing climates, vegetation, and tectonic events. Annual Review of Ecology and Systematics 24:467-500.

Kraglievich, L. 1926. Sobre el conducto humeral en las vizcachas y paquirucos chapadmalenses con descripción del Paedotherium imperforatum. Anales del Museo Nacional de Historia Natural 34:45-51.

Kraglievich, L. 1930. La Formación Friaseana del río Frías, río Fénix, Laguna Blanca, etc., y su fauna de mamíferos. Physis 10:127-161.

Kraglievich, L. 1934. La antigüedad Pliocena de las Faunas de Monte Hermoso y Chapadmalal, deducidas de su comparación con las que le precedieron y sucedieron. Imprenta "El Siglo Ilustrado," Montevideo, Uruguay, $136 \mathrm{pp}$.

Legendre, P., and L. Legendre. 1998. Numerical Ecology, second edition. Elsevier, Amsterdam, The Netherlands, $853 \mathrm{pp}$.

Marshall, L. G., and B. Patterson. 1981. Geology and geochronology of the mammal-bearing Tertiary of the Valle de Santa María and Río Corral Quemado, Catamarca Province, Argentina. Fieldiana, Geology (new series) 9:1-80.

Marshall, L. G., and T. Sempere. 1991. The Eocene to Pleistocene vertebrates of Bolivia and their stratigraphic context: a review; pp. 631652 in R. Suarez-Soruco (ed.), Fósiles y Facies de Bolivia, Volúmen I-Vertebrados. Revista Técnica de YPFB 12.

Marshall, L. G., R. Hoffstetter, and R. Pascual. 1983. Mammals and Stratigraphy: Geochronology of the Continental Mammal-Bearing Tertiary of South America. Palaeovertebrata, Montpellier, Memoire Extraordinaire, $93 \mathrm{pp}$.

Meyen, F. J. F. 1833. Das Vizcacha der Peruaner. Nova Acta Academiae Caesareae Leopoldino-Carolinae Germanicae Naturae Curiosorum 16:576-580

Pascual, R. 1961. Un nuevo Cardiomyinae (Rodentia, Caviidae) de la Formación Arroyo Chasicó (Plioceno inferior) de la Provincia de Buenos Aires. Ameghiniana 2:61-71.

Pascual, R. 1965. Los Toxodontidae (Toxodonta, Notoungulata) de la Formación Arroyo Chasicó (Plioceno inferior) de la Prov. de 
Buenos Aires. Características geológicas. Ameghiniana 4: 101-132.

Pascual, R. 1966. Vertebrata; pp. 1-202 in A. V. Borrello (ed.), Paleontografía Bonaerense, Volume 1. Comisión de Investigaciones Científicas de la Provincia de Buenos Aires, Buenos Aires, Argentina.

Pascual, R. 1967. Los roedores Octodontoidea (Caviomorpha) de la Formación Arroyo Chasicó (Plioceno inferior) de la Provincia de Buenos Aires. Revista del Museo de La Plata (Paleontología) 5:259282.

Pascual, R., and P. Bondesio. 1968. Los Cardiatheriinae (Rodentia, Caviomorpha) de la Formación Arroyo Chasicó (Plioceno inferior) de la provincia de Buenos Aires. Ameghiniana 5:237-251.

Pascual, R., and P. Bondesio. 1982. Un roedor Cardiatheriinae (Hydrochoeridae) de la Edad Huayqueriense (Mioceno tardío) de La Pampa: sumario de los ambientes terrestres en la Argentina durante el Mioceno. Ameghiniana 19:19-35.

Pascual, R., E. Ortiz Jaureguizar, and J. Prado. 1996. Land mammals: paradigm for Cenozoic South American geobiotic evolution; pp 265-319 in G. Arratia (ed.), Contributions of Southern South America to Vertebrate Paleontology. Münchner Geowissenschaftliche Abhandlungen (A) 30.

Pascual, R., J. Ortega Hinojosa, D. Gondar, and E. P. Tonni. 1965. Las Edades del Cenozoico mamalífero de la Argentina, con especial atención a aquellas del territorio bonaerense. Anales de la Comisión de Investigaciones Científicas de la Provincia de Buenos Aires 6:165-193.

Patton, J. L. 1987. Species group of spiny rats, genus Proechimys (Rodentia: Echimyidae). Fieldiana: Zoology New Series 39: 305-346.

Pérez, M. E., M. G. Vucetich, and C. M. Deschamps. 2014. Mandibular remains of Procardiomys martinoi Pascual, 1961 (Hystricognathi, Cavioidea) from the Arroyo Chasicó Formation (early late Miocene) of Argentina: anatomy and the phylogenetic position of the genus within Caviidae. Historical Biology 26:16-25.

Prado, J. L., and E. Cerdeño. 1998. Los mamíferos pliocenos de la Fauna Local Quequén Grande (Provincia de Buenos Aires, Argentina). Estudios Geológicos 54:75-83.

Quintana, C. A. 1996. Diversidad del roedor Microcavia (Caviomorpha, Caviidae) de América del Sur. Mastozoología Neotropical 3:63-86.

Rasia, L. L. 2016. Los Chinchillidae (Rodentia, Caviomorpha) fósiles de la República Argentina: sistemática, historia evolutiva y biogeográfica, significado bioestratigráfico y paleoambiental. Ph.D. dissertation, Facultad de Ciencias Naturales y Museo, Universidad Nacional de La Plata, La Plata, Argentina, 381 pp.

Rasia, L. L., and A. M. Candela. 2013. Systematic and biostratigraphic significance of a chinchillid rodent from the Pliocene of eastern Argentina. Acta Palaeontologica Polonica 58:241-254.

Rasia, L. L., A. M. Candela, and D. A. Flores. 2011. Sexual dimorphism in living and fossil plains viscachas (Rodentia, Caviomorpha, Chinchillidae) of Argentina: a qualitative approach. Ameghiniana 48: R196-R197.

Reguero, M. A., and A. M. Candela. 2011. Late Cenozoic mammals from the northwest of Argentina; pp. 411-426 in J. A. Salfity and R. A. Marquillas (eds.), Cenozoic Geology of the Central Andes of Argentina. SCS, Salta.

Rovereto, C. 1914. Los estratos araucanos y sus fósiles. Anales del Museo Nacional de Historia Natural de Buenos Aires 25:1-247.

Schultz, P., M. A. Zárate, B. Hames, C. Koeberl, T. Bunch, D. Storzer, P. Renne, and J. Wittke. 2004. The Quaternary impact record from the Pampas, Argentina. Earth and Planetary Science Letters 219:221-238

Scott, W. B. 1905. Mammalia of the Santa Cruz Beds. Vol. 5, Paleontology. Part 3, Glires; pp. 384-490 in W. B. Scott (ed.), Reports of the Princeton University Expeditions to Patagonia, 1896-1899.
Princeton University, E. Schweizerbart'sche Verlagshandlung (E. Nägele), Stuttgart, Germany.

Spotorno, A., and J. L. Patton. 2015. Superfamily Chinchilloidea Bennet 1883; pp. 762-782 in J. L. Patton, U. F. J. Pardiñas, and G. D'Elía (eds.), Mammals of South America, Volume 2, Rodents, The University of Chicago Press, Chicago (Illinois) and London.

Tauber, A. A. 2005. Mamíferos fósiles y edad de la Formación Salicas (Mioceno tardío) de la sierra de Velasco, La Rioja, Argentina. Ameghiniana 42:443-460.

Tomassini, R. L., C. I. Montalvo, C. M. Deschamps, and T. Manera. 2013. Biostratigraphy and biochronology of the Monte Hermoso Formation (early Pliocene) at its type locality, Buenos Aires Province, Argentina. Journal of South American Earth Sciences 48:31-42.

Tonni, E. P., G. Scillato Yané, A. L. Cione, and A. Carlini. 1998. Bioestratigrafía del Mioceno continental en el curso inferior del arroyo Chasicó, provincia de Buenos Aires; p. 135 in VII Congreso Argentino de Paleontología y Bioestratigrafía (Bahía Blanca), octubre 1998

Tullberg, T. 1899. Ueber das System der Nagethiere: eine phylogenetische Studie. Nova Acta Regiae Societatis Scientiarium Upsaliensis 3:1-514.

Verzi, D. H., C. I. Montalvo, and C. M. Deschamps. 2008. Biostratigraphy and biochronology of the Late Miocene of central Argentina: evidence from rodents and taphonomy. Geobios 41:145-155.

Vucetich, M. G. 1984. Los roedores de la Edad Friasense (Mioceno medio) de Patagonia. Revista del Museo de La Plata (Nueva Serie), Paleontología 50 8:47-126.

Vucetich, M. G. 1986. Historia de los Roedores y Primates en Argentina: su aporte al conocimiento de los cambios ambientales durante el Cenozoico; pp. 157-165 in $4^{\circ}$ Congreso Argentino de Paleontología y Bioestratigrafía, Actas, Volume 2.

Vucetich, M. G. 1989. Rodents (Mammalia) of the Lacayani fauna revisited (Deseadan, Bolivia). Comparison with new Chinchillidae and Cephalomyidae from Argentina. Bulletin du Muséum National d'Histoire Naturelle $4{ }^{\text {ème }}$ sér., C 11:233-247.

Vucetich, M. G., and D. H. Verzi. 1995. Los roedores caviomorfos; pp. 213-225 in M. T. Alberdi, G. Leone, and E. P. Tonni (eds.) Evolución Biológica y Climática de la Región Pampeana durante los últimos cinco millones de años. Un ensayo de correlación con el Mediterráneo occidental. Monografías Museo Nacional de Ciencias Naturales de Madrid 12.

Vucetich, M. G., M. M. Mazzoni, and U. F. J. Pardiñas. 1993. Los roedores de la Formación Collón Curá (Mioceno medio), y la Ignimbrita Pilcaniyeu. Cañadón del Tordillo, Neuquén. Ameghiniana 30:361-381

Weir, B. J. 1974. The tuco-tuco and plains viscacha; pp. 113-128 in I. W. Rowlands and B. J. Weir (eds.), The Biology of Hystricomorph Rodents. Symposia of the Zoological Society of London 34.

Wiegmann, A. F. A. 1835. Bericht über die Fortschritte der Zoologie im Jahre 1834. Archiv für Naturgeschichte 1:255-348.

Wood, A. E. 1955. A revised classification of the rodents. Journal of Mammalogy 36:165-187.

Woods, C. A. 1972. Comparative myology of jaw, hyoid, and pectoral appendicular regions of New and Old World hystricomorph rodents. Bulletin of the American Museum of Natural History 147:115-198.

Woods, C. A., and E. B. Howland. 1979. Adaptive radiation of capromyid rodents: anatomy of the masticatory apparatus. Journal of Mammalogy 60:95-116.

Zárate, M. A., P. H. Schultz, A. Blasi, C. Heil, J. King, and W. Hames, 2007. Geology and geochronology of type Chasicoan (late Miocene) mammal-bearing deposits of Buenos Aires (Argentina). Journal of South American Earth Sciences 23:81-90.

Submitted June 5, 2016; revisions received July 27, 2016; accepted July 28, 2016.

Handling editor: Marcelo Sánchez-Villagra. 